\title{
K-4, A NOVEL INHIBITOR OF ANGIOTENSIN I CONVERTING ENZYME PRODUCED BY ACTINOMADURA SPICULOSOSPORA
}

\author{
Toshiro Koguchi*, KoJi Yamada, Masayuki Yamato, Ryo Okachi, \\ KiYOSHI NAKAYAMA ${ }^{\dagger}$ and Hiroshi KaSE \\ Tokyo Research Laboratory, Kyowa Hakko Kogyo Co., Ltd., \\ 3-6-6 Asahimachi, Machida-shi, Tokyo 194, Japan
}

(Received for publication November 21, 1985)

\begin{abstract}
A novel inhibitor of angiotensin I converting enzyme (ACE), named $\mathrm{K}-4$, was isolated from the culture broth of Actinomadura spiculosospora nov. sp. K-4. The K-4 was an oligopeptide containing L-phenylalanine with $(R)$-1-amino-2-(4-hydroxyphenyl)ethylphosphonic acid as the $C$-terminal residue. The compound proved to be a specific and reversible inhibitor of ACE with the inhibition constant $(K i)$ of $0.18 \mu \mathrm{M}$, and inhibited ACE non-competitively by use of hippuryl-L-histidyl-L-leucine (HHL) as a substrate. When administrated intravenously to rats, $\mathrm{K}-4$ inhibited the pressor response to angiotensin I.
\end{abstract}

Much current attention has been focused on angiotensin I converting enzyme (ACE) inhibitors as antihypertensive drugs since the development of therapeutically effective inhibitors such as captopriil $^{1)}$.

In the course of our screening program from microbial origin, we found that an actinomycete strain identified as Actinomadura spiculosospora nov. sp. K-4 produced a novel ACE inhibitor designated $\mathrm{K}-4^{2}$.

In this communication, we report the production, isolation, physico-chemical and biological properties of $\mathrm{K}-4$.

The taxonomic studies of the producing organism and structure elucidation of $\mathrm{K}-4^{3)}$ will be published in separated papers.

\section{Materials and Methods}

Materials

Carboxypeptidase A (bovine pancreas) was obtained from Sigma. Carboxypeptidase B (porcine pancreas) was from Boehringer-Mannheim and $\alpha$-chymotrypsin (bovine pancreas) and trypsin (bovine pancreas) were purchased from Worthington Biochem.

Hippuryl-L-histidyl-L-leucine (HHL) and hippuryl-L-arginine were the products of Protein Research Foundation, Osaka. Hippuryl-L-phenylalanine was the product of Sigma. Benzoyl-L-tyrosine ethyl ester and p-tosyl-L-arginine methyl ester hydrochloride were from Nakarai Chemical Ltd. Leupeptin, antipain and chymostatin were purchased from Protein Research Foundation, Osaka.

Rabbit Lung Acetone Powder Extract

Rabbit lung acetone powder was extracted with 10 volumes of $50 \mathrm{~mm}$ sodium borate buffer, $\mathrm{pH}$ 8.3 , by stirring gently overnight at $4^{\circ} \mathrm{C}$ and centrifuged for 40 minutes at $40,000 \times g$. The supernatant which contained about 200 munits/ml of ACE activity was used for ACE assay.

$\dagger$ Present address: Zama Research Laboratory, Bior Co., Ltd., 5-5410 Hibariga-oka, Zama-shi, Kanagawa, Japan. 
Assays for Enzyme Inhibitory Activities

Inhibiton against ACE: Assay of ACE was based on the method of CUSHMAN and CHEUNG ${ }^{4)}$ by use of HHL as a substrate. The assay mixture (total volume, $300 \mu 1$ ) consisted of $3 \mathrm{~mm}$ HHL, $0.3 \mathrm{M} \mathrm{NaCl}, 50 \mathrm{~mm}$ sodium borate buffer, $\mathrm{pH} 8.3$, and $50 \mu \mathrm{l}$ of rabbit lung acetone powder extract (ca. 10 munits) with or without inhibitors. The reaction was started by the addition of $50 \mu 1$ of rabbit lung acetone powder extract and then the assay mixture was incubated for 30 minutes at $37^{\circ} \mathrm{C}$. The reaction was terminated by the addition of $250 \mu \mathrm{l}$ of $1 \mathrm{~N} \mathrm{HCl}$. The hippuric acid formed was extracted from the acidified solution into $1.5 \mathrm{ml}$ of ethyl acetate. After centrifugation (3,000 rpm, 15 minutes), $1 \mathrm{ml}$ of the upper layer was transferred into a glass tube and evaporated at $120^{\circ} \mathrm{C}$ for 30 minutes in vacuo. The hippuric acid was redissolved in $3.0 \mathrm{ml}$ of $50 \mathrm{~mm}$ sodium borate buffer, $\mathrm{pH} 8.3$, and quantified from its absorbance at $228 \mathrm{~nm}$. Hippuric acid formation increased linearly with time at least for 30 minutes.

Inhibition against Carboxypeptidase A, Carboxypeptidase B, Chymotrypsin and Trypsin: The assay mixtures (total volume of each assay tube, $3 \mathrm{ml}$ ) were as follows: $1 \mathrm{~mm}$ hippuryl-L-phenylalanine, $25 \mathrm{~mm}$ Tris- $\mathrm{HCl}$ containing $0.5 \mathrm{M} \mathrm{NaCl}(\mathrm{pH} 7.5)$ and 0.06 units $/ \mathrm{ml}$ enzyme for carboxypeptidase $\mathrm{A}^{5)}$; $1 \mathrm{~mm}$ hippuryl-L-arginine, $25 \mathrm{~mm}$ Tris- $\mathrm{HCl}$ containing $0.1 \mathrm{M} \mathrm{NaCl}(\mathrm{pH} 7.65)$ and 0.2 units $/ \mathrm{ml}$ enzyme for carboxypeptidase $\mathrm{B}^{\theta)} ; 0.5 \mathrm{~mm}$ benzoyl-L-tyrosine ethyl ester, $40 \mathrm{~mm}$ Tris- $\mathrm{HCl}$ containing $50 \mathrm{~mm}$ $\mathrm{CaCl}_{2}$ (pH 7.8) and 6 munits/ml enzyme for chymotrypsin ${ }^{7)} ; 1 \mathrm{~mm}$-tosyl-L-arginine methyl ester hydrochloride, $40 \mathrm{~mm}$ Tris- $\mathrm{HCl}$ containing $10 \mathrm{mM} \mathrm{CaCl}_{2}(\mathrm{pH} 8.1)$ and 0.15 units/ml enzyme for $\operatorname{trypsin}^{7)}$, with or without inhibitors. The reaction velocity was determined by measuring the increase in absorbancy at $254,254,256,247 \mathrm{~nm}$ for carboxypeptidases A, B, chymotrypsin and trypsin, respectively, with a Hitachi Model 200-20 Spectrophotometer. The assay was carried out at room temperature.

One unit of enzyme activity was defined as the amount of enzyme which catalyzed cleavage of $1 \mu \mathrm{mol}$ of a substrate per minute at $37^{\circ} \mathrm{C}$ for $\mathrm{ACE}$ and at room temperature for other enzymes.

Production

A 30 -liter jar fermentor containing 18 liters of the fermentation medium was inoculated with 0.9 liter of the seed culture grown in 2-liter Erlenmeyer flasks containing $300 \mathrm{ml}$ of the seed medium on a rotary shaker at $28^{\circ} \mathrm{C}$ for $2 \sim 3$ days.

The seed medium consisted of glucose $1 \%$, soluble starch $1 \%$, beef extract $0.3 \%$, yeast extract $0.5 \%$, Bacto-tryptone $0.5 \%$, and $\mathrm{CaCO}_{3} 0.2 \%$ (pH 7.2 before sterilization).

The fermentation medium consisted of soluble starch $4 \%$, soy bean meal $3 \%$, corn steep liquor $0.5 \%, \mathrm{~K}_{2} \mathrm{HPO}_{4} 0.05 \%, \mathrm{MgSO}_{4} \cdot 7 \mathrm{H}_{2} \mathrm{O} 0.05 \%, \mathrm{KCl} 0.03 \%$, and $\mathrm{CaCO}_{3} 0.3 \%(\mathrm{pH} 7.8$ before sterilization). Fermentation was carried out at $30^{\circ} \mathrm{C}$ with aeration (18 liters/minute) and agitation ( $\left.300 \mathrm{rpm}\right)$.

Measurement of the Pressor Response to Angiotensin I in Rats

Male Sprague-Dawley strain rats weighing about $350 \mathrm{~g}$ were anesthetized with urethane $(1.5 \mathrm{~g} /$ $\mathrm{kg}$, ip). Blood pressure was measured with a pressure transducer (Nihon Kohden, MPU-0.5A) through polyethylene cannula placed in the carotid artery and recorded on a polygraph (Nihon Kohden RM600). Angiotensins I and II were injected into the jugular vein. K-4 was injected from the tail vein.

\section{Results}

\section{Production}

A time course of fermentation is shown in Fig. 1. Total inhibitory activities against ACE increased rapidly during early logarithmic phase of growth and they reached a maximum at $80 \sim 100$ hours of incubation.

\section{Isolation}

A flow diagram for the isolation of K-4 is shown in Fig. 2. The broth was filtered and the filtrate was adjusted to $\mathrm{pH} 7.0$ with $6 \mathrm{~N} \mathrm{HCl}$. The filtrate (15 liters) was passed through a Diaion HP-10 
Fig. 1. Time course of fermentation.

Fermentation was carried out in a 30-liter jar fermentor at conditions described in Materials and Methods. The assay mixture for determination of inhibition against ACE consisted of the components described in Materials and Methods and $10 \mu 1$ of the broth supernatant.

Growth was expressed as packed cell volume that was determined by centrifugation at 3,000 rpm for 15 minutes.
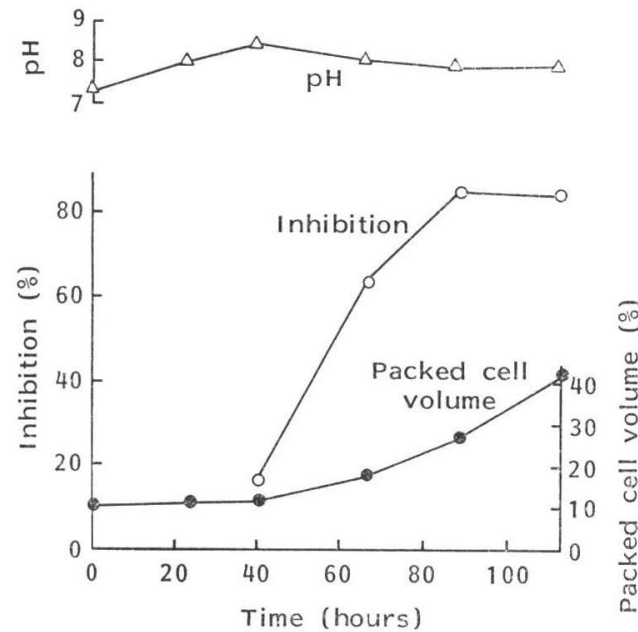

Fig. 2. Isolation of K-4.

Broth filtrate (15 liters)

|

Diaion HP-10 (1 liter)

eluted with $50 \% \mathrm{MeOH}$

concentrated in vacuo

freeze-dried

Avicel (1 liter)

eluted with $70 \% 2$-PrOH

concentrated in vacuo

adjusted to $\mathrm{pH} 7.5$

DEAE-Sephadex A-25 (500 ml)

eluted with $0.5 \mathrm{M}$ potassium phosphate buffer ( $\mathrm{pH} 7.5)$

adjusted to $\mathrm{pH} 7.0$

Diaion HP-10 $(100 \mathrm{ml})$

eluted with $50 \% \mathrm{MeOH}$

Active fractions

allowed to stand in a refrigerator

White fine crystalline powder $(5 \mathrm{mg})$

column (1 liter, Mitsubishi Chemical Industries Ltd.). After the column was washed with water, the active material was eluted with $50 \%$ methanol, concentrated in vacuo, and freeze-

dried. The freeze-dried material was put on an Avicel column (1 liter, Asahi Chemical Industry Co., Ltd.) which was developed with 70\% 2-propyl alcohol. The active fractions were pooled, concentrated in vacuo, adjusted to pH 7.5 and adsorbed on a DEAE-Sephadex A-25 column ( $500 \mathrm{ml}$, Pharmacia) equilibrated with $10 \mathrm{~mm}$ potassium phosphate buffer, $\mathrm{pH}$ 7.5. The column was washed with the same buffer and the active fractions eluted with $0.5 \mathrm{~m}$ potassium phosphate buffer, $\mathrm{pH} 7.5$, were com-

Table 1. Physico-chemical properties of K-4.

\begin{tabular}{|c|c|c|}
\hline \multicolumn{2}{|l|}{ Appearance } & White fine crystalline powder \\
\hline \multirow[t]{2}{*}{ Solubility } & Soluble & $0.1 \mathrm{~N} \mathrm{NaOH}$ \\
\hline & Insoluble & EtOAc, chloroform, benzene, $n$-hexane \\
\hline \multicolumn{2}{|l|}{$\mathrm{MP}\left({ }^{\circ} \mathrm{C}\right)$} & $>300$ \\
\hline \multicolumn{2}{|c|}{ Optical rotation } & {$[\alpha]_{\mathrm{D}}^{20}-83^{\circ}(c 0.1,0.1 \mathrm{~N} \mathrm{NaOH})$} \\
\hline \multirow[t]{2}{*}{$\mathrm{UV} \lambda_{\max } \mathrm{nm}$} & $0.1 \mathrm{~N} \mathrm{HCl}$ & $275,280(\mathrm{sh})$ \\
\hline & $0.1 \mathrm{~N} \mathrm{NaOH}$ & 240,292 \\
\hline \multicolumn{2}{|c|}{ Color reaction Positive } & Rydon-Smith, $\mathrm{I}_{2}$ \\
\hline & Negative & Ehrlich \\
\hline \multirow[t]{3}{*}{ TLC (Rf)* } & $70 \% 2-\mathrm{PrOH}$ & 0.37 \\
\hline & $\begin{array}{l}\mathrm{BuOH}-\mathrm{AcOH}-\mathrm{H}_{2} \mathrm{O} \\
\quad(4: 1: 1)\end{array}$ & 0.37 \\
\hline & $\begin{array}{l}\mathrm{BuOH}-\mathrm{PrOH}-\mathrm{H}_{2} \mathrm{O} \\
\quad(2: 1: 1, \text { upper layer })\end{array}$ & 0.18 \\
\hline \multicolumn{2}{|c|}{ Amino acid analysis } & $\begin{array}{l}\text { Phe : (R)-1-amino-2-(4-hydroxyphenyl)ethylphosphonic acid } \\
\quad(c a .1: 1)\left(6 \mathrm{~N} \mathrm{HCl}, 110^{\circ} \mathrm{C}, 20 \text { hours }\right)\end{array}$ \\
\hline \multicolumn{2}{|c|}{ Hydrazinolysis } & (R)-1-Amino-2-(4-hydroxyphenyl)ethylphosphonic acid \\
\hline
\end{tabular}

* Silica gel 60 (Merck, Art. 5721). 
Fig. 3. UV spectra of K-4.

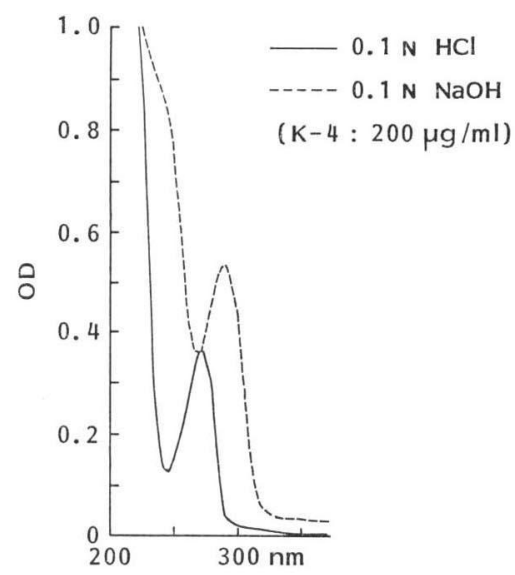

bined, adjusted to $\mathrm{pH} 7.0$, and then passed through a Diaion HP-10 column $(100 \mathrm{ml})$. After washing the column with water, the active material was eluted with $50 \%$ methanol and the active fractions were allowed to stand in a refrigerator. Then, white fine crystalline powder of K-4 (5 mg) was precipitated.

\section{Physico-chemical Properties}

The physico-chemical properties of $\mathrm{K}-4$ are listed in Table 1. The UV spectrum of K-4 is shown in Fig. 3 and the IR spectrum is shown in Fig. 4. Acid hydrolysis of $\mathrm{K}-4\left(6 \mathrm{~N} \mathrm{HCl}, 110^{\circ} \mathrm{C}\right.$, 20 hours) gave phenylalanine and an unidentified

Fig. 4. IR spectrum of $\mathrm{K}-4(\mathrm{KBr})$.

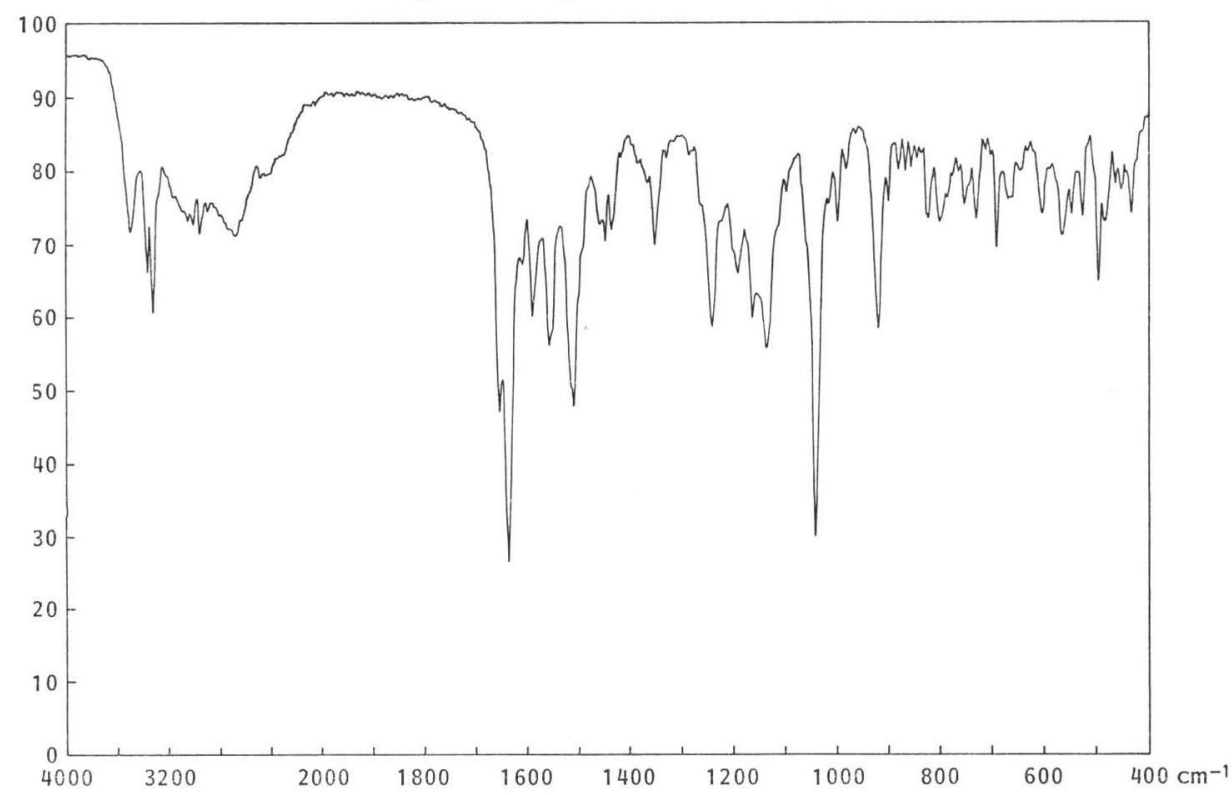

Table 2. Specificity of K-4.

\begin{tabular}{lccccc}
\hline & \multicolumn{5}{c}{ Inhibition (\%) } \\
\cline { 2 - 6 } & K-4 & Leupeptin & Antipain & Chymostatin & $\begin{array}{c}\beta \text {-Phenyl- } \\
\text { propionic acid }\end{array}$ \\
\hline ACE & 100 & 18.3 & 4.1 & 21.1 & 0 \\
Carboxypeptidase A & 2.3 & 0 & 0 & 0 & 60 \\
Carboxypeptidase B & 0 & 0 & 0 & 0 & NT \\
Chymotrypsin & 0 & 0 & 0 & 100 & NT \\
Trypsin & 0 & 92.0 & 93.0 & 0 & NT \\
\hline
\end{tabular}

Substrates are as follows; HHL for ACE, hippuryl-L-phenylalanine for carboxypeptidase A, hippuryl$\mathrm{L}$-arginine for carboxypeptidase $\mathrm{B}$, benzoyl-L-tyrosine ethyl ester for chymotrypsin, and $p$-tosyl-L-arginine methyl ester for trypsin.

The concentration of each inhibitor in each assay was $33.3 \mu \mathrm{g} / \mathrm{ml}$.

NT; Not tested. 
Fig. 5. Effect of preincubation.

The mixture $(100 \mu \mathrm{l})$ containing ACE 10.6 munits, $50 \mathrm{~mm}$ sodium borate buffer ( $\mathrm{pH} 8.3$ ) with $0.05 \mu \mathrm{g}$ of $\mathrm{K}-4$ was preincubated for indicated time. Then, the substrate solution $(200 \mu \mathrm{l})$ consisting of $4.5 \mathrm{~mm}$ HHL and $50 \mathrm{~mm}$ sodium borate buffer ( $\mathrm{pH} 8.3$ ) was added to the mixture. The enzyme reaction proceeded at $37^{\circ} \mathrm{C}$ for 15 minutes. The enzyme activity determined without $\mathrm{K}-4$ and preincubation time was expressed as $0 \%$ inhibition.

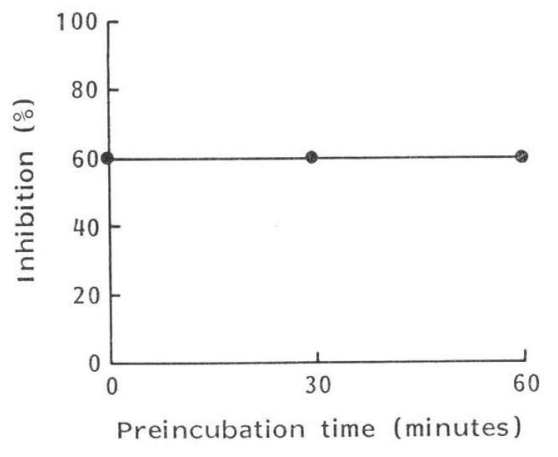

ninhydrin-positive substance. The molar ratio of phenylalanine and the unidentified substance was determined to be about $1: 1$ with a Jeol JIC200A automated amino acid analyzer. The unidentified substance was identified as $(R)$-1-amino2 - (4 - hydroxyphenyl)ethylphosphonic $\operatorname{acid}^{3)}$. Phenylalanine had the L-configuration ${ }^{3)}$. By the method of hydrazinolysis for the determination of $C$-terminal residues of peptides ${ }^{8)},(R)-1$ amino-2-(4-hydroxyphenyl)ethylphosphonic acid was detected, which gave the Rf value of 0.29 on cellulose TLC with the solvent system, butanol acetic acid-water, $4: 1: 1$. K-4 was suggested to be an oligopeptide containing phenylalanine with the aminophosphonic acid, $(R)-1$-amino-2(4-hydroxyphenyl)ethylphosphonic acid as the $C$-terminal residue.

Inhibitory Activities of K-4 against ACE and Other Proteases

K-4 strongly inhibited ACE in a dose dependent manner. The concentration of K-4 required for half-maximal inhibition $\left(\mathrm{IC}_{50}\right)$ against $\mathrm{ACE}$ was $0.08 \mu \mathrm{g} / \mathrm{ml}$. The acid hydrolyzate of $\mathrm{K}-4$ had no inhibitory activity against $\mathrm{ACE}\left(\mathrm{IC}_{50}>150 \mu \mathrm{g} / \mathrm{ml}\right)$. Therefore, an unusual aminophosphonic acid, $(R)$-1-amino-2-(4-hydroxyphenyl)ethylphosphonic acid alone was suggested to have no inhibitory activity against $\mathrm{ACE}$.

Fig. 6. Lineweaver-Burk plots a) and Dixon plots b) of inhibition of ACE by K-4.

The ACE assay was carried out under conditions described in Materials and Methods except that the reaction proceeded at $37^{\circ} \mathrm{C}$ for 20 minutes. Hippuric acid formed increased linearly with time at least for 20 minutes when $2 \mathrm{~mm}$ was used as a substrate.

a) $0 ; \mathrm{K}-40 \mathrm{ng} / \mathrm{ml}, \Delta ; \mathrm{K}-433 \mathrm{ng} / \mathrm{ml}, \mathbf{A} ; \mathrm{K}-4165 \mathrm{ng} / \mathrm{ml}$, ; captopril $3.3 \mathrm{ng} / \mathrm{ml}$.

b) $\square$; HHL $2 \mathrm{~mm}$, 葍; HHL $3 \mathrm{~mm}, \nabla$; HHL $5 \mathrm{~mm}$.

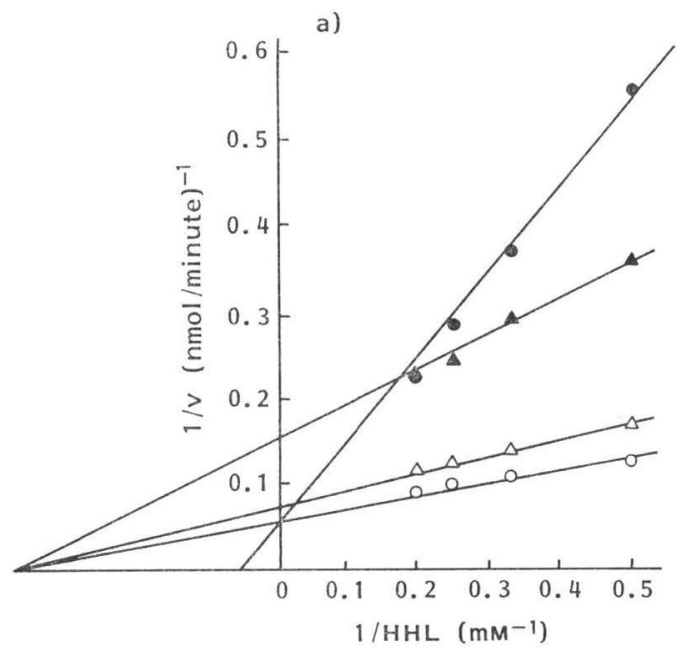

b)

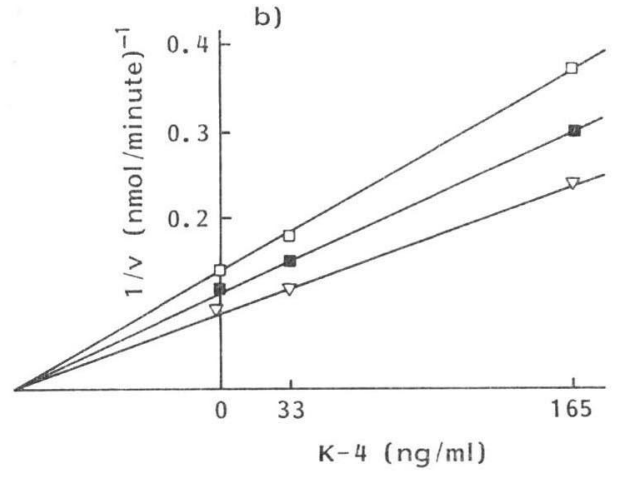


Fig. 7. Specific inhibition of pressor response to angiotensin I (AG I) in rats by K-4.

a) The pressor response to angiotensins I and II (each, $0.3 \mu \mathrm{g} / \mathrm{kg}$, iv) in control rats.

b) After iv injection of $\mathrm{K}-4(1 \mathrm{mg} / \mathrm{kg}$, iv), the pressor response to angiotensins I and II (each, $0.3 \mu \mathrm{g} / \mathrm{kg}$, iv) was measured.

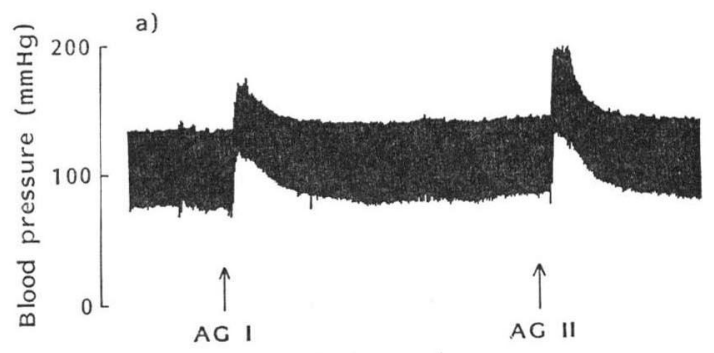

Table 3. ACE inhibitory activities and antimicrobial activities of K-4 and phosphonic acid-containing antimicrobial agents.

\begin{tabular}{lcc}
\hline Compounds & $\begin{array}{c}\text { Inhibition } \\
\text { against } \\
\text { ACE }(\%)^{*}\end{array}$ & $\begin{array}{c}\text { Inhibition zone } \\
\text { (against E. coli } \\
\text { ATCC 26) } \\
\text { (mm)** }\end{array}$ \\
\hline K-4 & 100 & None \\
Fosfomycin & 0 & 28 \\
FR-31564 & 0 & 22 \\
FR-90098 & 0 & 20 \\
FR-900137 & 0 & 25 \\
Alaphosphin & 0 & 37 \\
\hline
\end{tabular}

* The concentration of each compound in each assay tube for ACE assay was $33.3 \mu \mathrm{g} / \mathrm{ml}$.

** A $40 \mu \mathrm{g}$ of each compound was put on a paper disc $(7 \mathrm{~mm}$ in diameter) for agar diffusion assay. The agar medium consisted of glucose $0.5 \%,\left(\mathrm{NH}_{4}\right)_{2} \mathrm{SO}_{4} 0.4 \%, \mathrm{KH}_{2} \mathrm{PO}_{4} 0.1 \%, \mathrm{NaCl}$ $0.1 \%, \quad \mathrm{FeSO}_{4} \cdot 7 \mathrm{H}_{2} \mathrm{O} \quad 0.07 \%, \quad \mathrm{MgSO}_{4} \cdot 7 \mathrm{H}_{2} \mathrm{O}$ $0.07 \%$ and agar $1.5 \%$.

Inhibition of K-4 against carboxypeptidase A, carboxypeptidase $\mathrm{B}$, chymotrypsin and trypsin was investigated to study the specificity of $\mathrm{K}-4$. Inhibition of leupeptin, antipain, chymostatin, and $\beta$-phenylpropionic acid ${ }^{\text {) }}$ (a carboxypeptidase A inhibitor) against these enzymes was tested as control experiments. Table 2 shows the results. The concentration of each inhibitor in each assay was $33.3 \mu \mathrm{g} / \mathrm{ml}$. Leupeptin and antipain, chymostatin, and $\beta$-phenylpropionic acid strongly inhibited trypsin, chymotrypsin, and carboxypeptidase A, respectively, but at the same conditions, $\mathrm{K}-4$ did not inhibit the proteases. The results indicated that $\mathrm{K}-4$ was a specific inhibitor of ACE.

After ACE and $\mathrm{K}-4$ were pre-incubated at $37^{\circ} \mathrm{C}$ for $0 \sim 60$ minutes, the substrate solution was added to the mixture and then the enzyme reaction proceeded at $37^{\circ} \mathrm{C}$ for 15 minutes. Fig. 5 indicated that the inhibition of $\mathrm{K}-4$ against $\mathrm{ACE}$ was not affected by the preincubation time. The reaction mixture (2 ml) containing ACE 10.6 munits, K-4 $100 \mu \mathrm{g}$ and 50 mM sodium borate buffer, $\mathrm{pH} 8.3$, was incubated 
at $37^{\circ} \mathrm{C}$ for 75 minutes. This solution had no ACE inhibitory activity. The solution was dialyzed overnight at $4^{\circ} \mathrm{C}$ against $50 \mathrm{~mm}$ sodium borate buffer, $\mathrm{pH} 8.3$; ACE inhibitory activity of this solution was completely recovered. These results indicated that $\mathrm{K}-4$ was not decomposed by ACE at least for 60 minutes at $37^{\circ} \mathrm{C}$ and that the inhibition of K-4 against ACE is not progressive and irreversible, but reversible.

As shown in Fig. 6, K-4 was a non-competitive inhibitor against ACE by use of HHL as a substrate whereas captopril was a competitive inhibitor as reported previously ${ }^{10)}$. The $K i$ value of $\mathrm{K}-4$ was $0.18 \mu \mathrm{M}$. The linearity of Dixon plots suggested that one molecule of K-4 inhibited one molecule of ACE.

$\mathrm{K}-4$ contained the phosphonic acid-containing residue, $(R)$-1-amino-2-(4-hydroxyphenyl)ethylphosphonic acid, as the $C$-terminal residue as described above. Since fosfomycin ${ }^{11}$, FR-31564 ${ }^{12}$, FR-90098 ${ }^{12)}$, FR-900137 $7^{13)}$, and alaphosphin ${ }^{14)}$, etc. are known to be phosphonic acid-containing antimicrobial agents, antimicrobial activity of K-4 against Escherichia coli and ACE inhibitory activity of these phsophonic acid-containing antimicrobial agents were tested. As shown in Table 3, K-4 had no antimicrobial activity and the phosphonic acid-containing antimicrobial agents had no ACE inhibitory activities.

Inhibition of the Pressor Response to Angiotensin I in Rats by K-4

Fig. 7a shows the pressor response to angiotensins I and II (each, $0.3 \mu \mathrm{g} / \mathrm{kg}$, iv) in rats. The pressor response to angiotensin I $(0.3 \mu \mathrm{g} / \mathrm{kg}$, iv) was completely inhibited by the previous administration of K-4 (1 mg/kg, iv), but the pressor response to angiotensin II $(0.3 \mu \mathrm{g} / \mathrm{kg}$, iv) was not (Fig. $7 \mathrm{~b})$. The results indicated that inhibition of the pressor response to angiotensin I in rats by K-4 was due to inhibition of ACE. The pressor response to angiotensin I $(0.3 \mu \mathrm{g} / \mathrm{kg}$, iv) was inhibited in a dose dependent manner over $0.1 \mathrm{mg} / \mathrm{kg}$ of $\mathrm{K}-4$ (iv injection, 5 minutes before injection of angiotensin I). The $\mathrm{IC}_{50}$ of $\mathrm{K}-4$ was $0.21 \mathrm{mg} / \mathrm{kg}$ (Fig. 8).

\section{Discussion}

We found that $A$. spiculosospora nov. sp. K-4 produced K-4, a novel inhibitor of $\mathrm{ACE}^{2)}$. Later, KIDo et al. ${ }^{15)}$ reported I5B1 from an Actinomadura strain, which was identical with K-4.

K-4 contains an unusual aminophosphonic acid, $(R)$-1-amino-2-(4-hydroxyphenyl)ethylphosphonic acid as the $C$-terminal residue as do $\mathrm{K}-26^{16)}$ and I5B2 ${ }^{15)}$. (R)-1-Amino-2-(4-hydroxyphenyl)ethylphosphonic acid alone was shown to have no inhibitory activity against ACE. Phosphonic acidcontaining antimicrobial agents such as fosfomycin, FR-31564, FR-90098, FR-900137 and alaphosphin did not inhibit ACE. K-4 potently inhibited ACE, but did not inhibit carboxypeptidases $\mathrm{A}$ and B. All three enzymes contain $\mathrm{Zn}^{2+}$ at the active sites. However, it is possible that the phosphonic acid moiety of K-4 binds to $\mathrm{Zn}^{2+}$ at the active site of ACE. K-4 was a reversible inhibitor of ACE and inhibited ACE non-competitively by use of HHL as a substrate, whereas captopril was a competitive inhibitor. The hypothetical model of the binding site on ACE of captopril and HHL was proposed by Cushman et al. ${ }^{1,10)}$. The binding site of $\mathrm{K}-4$, even though it is a part of the binding site of angiotensin I, is possibly different from that of captopril and HHL.

\section{References}

1) Ondetti, M. A.; B. Rubin \& D. W. Cushman: Design of specific inhibitors of angiotensin-converting enzyme. New class of orally active antihypertensive agents. Science 196: 441 443, 1977

2) Koguchi, T.; H. Kase, I. Kawamoto, M. Kasai, K. Shirahata, R. Okachi \& K. Nakayama: A novel 
physiologically active substance K-4 and its preparation. Japan Kokai 83-31,992, Feb. 24, 1983

3) Kasai, M.; M. Yoshida, N. Hirayama \& K. Shirahata: Structure elucidation of new inhibitors of angiotensin I converting enzyme, K-26 and K-4. Symposium papers of 27th Symposium on the Chemistry of Natural Products. pp. 577 584, Hiroshima, Oct. $15 \sim 18,1985$

4) Cushman, D. W. \& H. S. Cheung: Spectrophotometric assay and properties of the angiotensin-converting enzyme of rabbit lung. Biochem. Pharmacol. 20: 1637 1648, 1971

5) Folk, J. E. \& E. W. Schirmer: The porcine pancreatic carboxypeptidase A system. J. Biol. Chem. 238: $3884 \sim 3894,1963$

6) Folk, J. E.; K. A. Pietz, W. R. Carroll \& J. Gladner: Carboxypeptidase B. IV. Purification and characterization of the porcine enzyme. J. Biol. Chem. 235: 2272 2277, 1960

7) Hummel, B. C. W.: A modified spectrophotometric determination of chymotrypsin, trypsin and thrombin. Can. J. Biochem. Physiol. 37: 1393, 1959

8) Akabori, S.; K. Ohno \& K. Narita: On the hydrazinolysis of proteins and peptides: A method for the characterization of carboxy-terminal amino acids in proteins. Bull. Chem. Soc. Jpn. 25: 214 218, 1952

9) Petra, P. H.: Bovine procarboxypeptidase and carboxypeptidase A. Methods Enzymol. 19: 460 503, 1970

10) Cushman, D. W.; H. S. Cheung, E. F. Sabo \& M. Ondetti: Design of new antihypertensive drugs: Potent and specific inhibitors of angiotensin-converting enzyme. Prog. Cardiovasc. Dis. 21: 176 186, 1987

11) Hendlin, D.; E. O. Stapley, M. Jakson, H. Wallick, A. K. Miller, F. J. Wolf, T. W. Miller, L. Ohaiet, F. Kahan, E. L. Flotz, H. B. Mata, S. Hermandetz \& S. Mochales: Phosphonomycin, a new antibiotic produced by strain of Streptomyces. Science 66: 122 125, 1969

12) Kamiya, T.; K. Hemmi, H. Takeno \& M. Hashimoto: Studies on phosphonic acid antibiotics. I. Structure and synthesis of 3-( $N$-acetyl- $N$-hydroxyamino)-propylphosphonic acid (FR-90098) and its $N$-formyl analogue (FR-31564). Tetrahedron Lett. 21: 95 98, 1980

13) Kuroda, Y.; H. Tanaka, M. Okamoto, T. Goto, M. Kohsaka, H. Aoki \& H. Imanaka: FR-900137, A new antibiotic. II. Structure determination of FR-900137. J. Antibiotics 33: 280 283, 1980

14) Allen, J. G.; F. R. Atherton, M. J. Hall, C. H. Hasal, S. W. Holmes, R. W. Lambert, L. J. Nisbert \& P. S. Ringros: Phosphonopeptides, a new class of synthetic antibacterial agents. Nature 272: 56 58,1978

15) Kido, Y.; T. Hamakado, M. Anno, E. Miyagawa, Y. Motoki, T. Wakamiya \& T. Shiba: Isolation and characterization of I5B2, a new phosphorus containing inhibitor of angiotensin I converting enzyme produced by Actinomadura sp. J. Antibiotics 37: 965 969, 1984

16) Yamato, M.; T. Koguchi, R. OKachi, K. Yamada, K. Nakayama, H. Kase, A. Karasawa \& K. Shuto: K-26, a novel inhibitor of angiotensin I converting enzyme produced by an actinomycete K-26. J. Antibiotics 39: $44 \sim 52,1986$ 